\title{
Bridge Over the Rainbow. Animal Burials and Animal Cemeteries in Post-Socialist Estonia
}

\author{
Marju Kõivupuu
}

\author{
Centre of Culture and Landsape, the School of Humanities, Tallinn \\ University \\ marju.koivupuu@tlu.ee
}

\begin{abstract}
Ritual burials for animals have been practiced both ancient advanced cultures (like Egypt) and prehistoric peoples. As a factor accompanying the Industrial Revolution at the end of the 19th century, cemeteries for pets began to appear in the vicinity of bigger cities, and pet culture as a whole formed a separate economic branch. In industrial society the topic of pets became so important that in 1978 Errol Morris produced his widely acclaimed documentary Gates of Heaven, which focused on the business of animal burials.

This article reviews the change in animal burial practices, focusing on the practices found in post-socialist Estonia, where the phenomenon is rather new because of various socio-cultural reasons. As a result of this newness, the phenomenon is causing opposing opinions in society.
\end{abstract}

Key words: Death culture; anthropomorphism; pet culture; pet cemeteries; popular religion.

\section{Introduction}

The best place to bury a good dog is in the heart of her master. - Anonymous

Animals have their own culture, history and ethnology, and animals have been an important part of human culture for thousands of years (Premack \& Premack 2002: 350-351). Animal history and culture as a subject of study in ethnology (i.e. the relationship of people and animals through the ages, values, qualities and meanings ascribed to animals) are human-mediated and constructed.

Every generation has had its own point of view of animals as creatures who do not have all that we have as humans, such as language, consciousness, intellect and morality. At the same time, we are reminded that people are animals - mammals, specifically - and the best way to determine what being human means is to compare us to other animals (Ingold 2002: 14-15). Because animals have been 
an important part of human culture for thousands of years, animals can talk-adaptation, or rather the adaptation of human culture. This relates to animals that live among people: domesticated animals, pets, etc. Dominique Lestel indicates that even a hybrid of human and animal communities, where people live with pets and domestic animals, exists (Lestel 2002: 203).

Evidence about love towards pets is to be found in ancient history. However, historians and ethnologists are still arguing whether this love existed from the beginning or formed in the process of general development. According to some scientists, primitive peoples started domesticating animals for magical reasons; hunters were trying to redeem themselves for the prey that they killed.

The human-animal relationship has changed significantly compared to the past. Rational peasant culture has not known nor acknowledged pet culture. Although the agricultural animal (domestic animal) is thought to have a soul, its tiny soul has always been located lower on the spiritual hierarchy. Estonians have, for example, said that humans have souls but brutes have warm breath. Although children might have had and did have their "own" animals in the household, their fate was still decided by adults. Peasant culture did not accept a pet as something "just for myself", to paraphrase Astrid Lindgren's character Pelle in the novel Seacrow Island (Lindgren 1969, 1993, 2000).

The concept of the pet has become particularly strong. People living in postmodern and technocratic urban society are more or less estranged from both uncultivated as well as cultivated nature and the natural processes taking place there. Probably for this reason pet today is not so much an animal as a favourite: he is halfway to being human (Torp-Kõivupuu 2004; Mikkor 2000; Ilomäki 2002: 15-16) and a member of the family, which is reflected in people's changing attitudes towards pets. Pets have a special status in human society: they have a name and they live with people who often give them moral values and qualities (Patoluoto 1989: 107-108 [cited in Ilomäki 2002: 16]; Kaaristo 2006).

Lack of human relationships also plays a significant role in pet culture; a furry friend often replaces a friend and a companion or even family and children for a lonely person (see Kruus 2004). 
However, pets do presuppose certain financial capacity: animal food, care products, medical help and their taking part in shows all require significant expense on the owner's account. Various researchers associate a decreased birth rate and the prevalence of the so-called small family model with the continued increased popularity of pet culture (see also Hyttinen 1996:139). Pet culture also improves contacts between humans in urban culture. People tend to interact more freely with an acquaintance or even a complete stranger walking a dog or a cat than with a person walking alone (Hyttinen 1996: 140).

A dog is a means for integration, "contemplates Tiit Truumaa, the head of Jõelähtme Pet Cemetery. "For example, if a woman walks her dog in the park, you go and talk to her about the dog. And there the relationship starts. Russians come to the kennel union where most people are Estonians. And the big love they have for their dog forces them to speak Estonian (Lepassalu \& Palli 2000: 39).

The dominating factor in human-pet relationships in a postmodern and technocratic society seems to be anthropomorphism - psychological qualities of humans are attributed to animals and they are often even dressed as humans (Hyttinen 1996: 139, Kruus 2004). ${ }^{1}$ In many cases this is due to practical necessity: the "fashion disease" of the 20th and 21st century has made it necessary, for people with allergies, to breed animals with short hair or those that are completely hairless which need clothes in a colder climate.

There are numerous websites where pet owners form virtual communities. At one time or another it is "in" to have a dog or a cat of this or that breed or even some other completely exotic friend. Different religious convictions and everyday understandings valid among pet owners and their intimates also play a role in choosing a pet. Even naming the pets is an anthropomorphist and humanistic act.

The pets of prominent persons have turned into media heroes. In the first days of January 2002, various media outlets, including print publications, featured the story about the tragic death of Bill Clinton's Labrador. The cat named Miisu, owned by of former Estonian Prime Minister Juhan Parts, who resided in the Stenbock building with the government, posed on the front pages of daily newspapers and turned into a key character in the political comedy 
show Pehmed ja karvased (Soft and Furry), which featured on the Estonian national TV channel ETV. So pets fill many and often simultaneous roles in our life - they can be symbols of social status, guardians for the house or an apartment, friends or companions on walks (Hyttinen 1996: 140).

If and how many different (exotic) pet animals/birds there are in modern cities can only be guessed. In 1995 the students of Tallinn Lasnamäe Kuristiku Secondary School questioned the people living in the neighbouring apartment blocks. Based on that survey it became clear that there were 335 dogs per 500 families in the apartment buildings. For example, in Tallinn, Russian families tend to have large pedigreed dogs for their children to compensate for the lack of contact with the natural world. Based on the results of the same questionnaire, large dogs are owned to protect the home from burglaries. Another significant fact is the theory that raising expensive pedigreed dogs improves the owners' self-esteem and prestige in society (Nerman 1998: 402). Various statistical data about the number of pets and the expenses made on them in a district/city of one or another country are also impressive and worth consideration. ${ }^{2}$

A pet has also become a symbol of status. Representatives of various nationalities and social groups have different beliefs, convictions and attitudes when it comes to pets and the pet culture as a whole. ${ }^{3}$

The pet culture as a wider phenomenon will also be briefly reviewed: its underlying causes, relation to modern industrial society and the Christian cultural space and anthropomorphist appearances in modern pet culture. With the arrival of the internet age, pet cemeteries, along with the final resting places for humans, moved to virtual reality. When we Google the term pet cemeteries we find interesting information on real as well as virtual pet cemeteries.

The article mainly focuses on one aspect of the pet culture - the changes in animal burial customs over time and their relationship to the owner's ethnic background and religious affiliation. The focus is on practice in post-socialist Estonia where the phenomenon is rather new because of various social-cultural reasons, which cause opposing opinions. The author tries to answer, among other things, the question of whether the pet cemetery culture in modern society 
testifies to the lack of human relationships, which causes the need to equalize a pet with a human being. Estonian pet owners have a superstitious warning - an excessive commitment to a pet decreases our potential to have offspring.

\section{Pets, death and pet cemeteries - an historical overview}

The friendship between animals and humans is so natural that we hardly ever think about how and when it began and for whom it was necessary. The relationship, which has in some cases reached the extent where masters basically guarantee human rights for their pets, has an interesting and very long history.

Pet cemeteries are not new to history. Throughout history, humans have demonstrated their love for and desire to bond with animals. They have shown animals the same respect in their passing as they do fellow humans by writing loving epitaphs and creating cemeteries and memorials specifically to remember beloved pets and animals (Pet cemeteries throughout the World 2006).

Archeologists (or archeozoologists, to be more precise) speak about animal funerals if an animal is buried in a separate grave or with a human. Animals were first buried during the Neolithic Age when agriculture was taking root. Most burials were for domestic animals (cows, horses, dogs) and, therefore, animal burials have been viewed as funeral objects or, in some cases, as sacrifices.

The carefully interred remains of a human and a cat were found buried with seashells, polished stones, and other decorative artefacts in a 9,500-year-old grave site on the Mediterranean island of Cyprus (Pickrell 2004). Ancient advanced cultures, including that of the Ancient Egyptians, have practised animal burials. Ancient Egyptians were known to mummify and bury cats - those animals were considered divine. ${ }^{4}$ Cats are frequently represented in Egyptian mythology in the form of the feline goddesses Bastet, Sekhmet and other deities. Cat art and mummified remains are known from as far back as 4,000 years ago (Pickrell 2004).

Ancient Egyptians' practice of animal burial is the best known, thanks to the many elaborately mummified dogs, cats, monkeys and birds that have been recovered by archaeologists in recent times. 
As early as $1000 \mathrm{BC}$, substantial parcels of land along the Nile were set aside expressly for the burial of animals, though it was equally acceptable to inter pets in the tombs of their owners. Then, as now, wealthy pet owners spared no expense for their animals' funerals. Among the most famous ancient dog lovers is Alexander the Great (356 BC - 323 BC), who owned a large mastiff-like hound named Peritas. Upon her death, the conqueror led a formal funeral procession to the grave, erected a large stone monument on the site and ordered nearby residents to celebrate her memory in annual festivities. A city by the name still exists in this location. (Thurston: http://www.petcem.com/historypetburials.html).

Pet cemeteries also existed in Greece in 300 BC because people there had dogs as pets. The richest people in Athens even had cheetahs or at least one singing bird at home. Horses were considered special animals at that time and luxury taxes applied for them. Archaeologists discovered two horses at the site of the ancient city of Ascalon located in the Gaza Strip controlled by Israel. In 1986 Laurence Stager's archaeological team discovered the ancient pet cemetery of Ascalon containing the remains of over $1000 \mathrm{dogs}$. This cemetery dates to the period of Persian rule (539-332 BC) in Palestine (Pet Memorials 2008).

Numerous animal burials have been found in the burial mounds of nobles dating from the Iron Age. For example, Lithuanian burial mounds contain many horse burials, while those of Livonians have more dogs. Ancient dog funerals were equal to human funerals. During the Mesolithic or Middle Stone Age the dog and human formed a pair of predators. Dogs were domesticated during the Neolithic Age (Jonuks 2006). Because of dogs' exceptional roles, including as hunters, they were buried as early as the Mesolithic Age. In Estonia there have been findings of burnt animal bones from cremations dating from the end of the Viking Age: the dog was burnt with the human body and in most cases a grown dog was sacrificed to the deceased (Jonuks 2006).

The closest Stone Age dog burials are from Northern Latvia in the Mesolithic part of Zveinjeki Cemetery; dog burials have also been found in the Mesolithic cemeteries of Southern Sweden, Skateholm - there the dog was buried with the human or in a separate grave clearly linked to the buried humans (Nilsson Stutz 2003: 
232, appendix 102). The dogs of Skateholm were regarded as very important animals. Similar to humans, contributions were placed in their grave or the body was covered with ochre (Larsson 2000: 91). In our region, dog burials were known in many places during the Viking Age and the late Iron Age. The first separate dog burials appeared in Scandinavia during the Roman Iron Age but became more widespread during the Vendel Period and achieved their peak during the Viking Period. It is noteworthy that Scandinavian dog burials were most widespread in Eastern Sweden, near Mälari, but they are also present in Skåne and Denmark, and to a lesser extent in Southwestern Finland (Makiewicz 2000). Dogs were often buried in the mounds of the Koiva Livonians, for example, in Krimulda (Tõnisson 1974: 54-64), whereby the discovered bones where most probably those of a large breed similar to a modern sheepdog (Tõnisson 1974: 56).

One of the first pet necropolises in the world is the pet cemetery decorated with glorious sculptures opened near Paris in 1889. Pet culture developed as a side product of the Industrial Revolution and the process of urbanization, and pet cemeteries were increasingly established near big cities (Hyttinen 1996, Wolf 1989, Wiedenmann 1993, Stark 1993). In industrial society the pet theme became so acute that in 1978 Errol Morris released the widely acclaimed documentary Gates of Heaven, which covered the topic of the burial business for pets. Gates of Heaven launched Morris' career and is now viewed as a classic. In 1981 Roger Ebert named it one of the ten best films of the year. The film's acclaim stems less from its coverage of pet cemeteries than how Morris builds on this base to explore issues such as morality and the afterlife. Although there are 19 known pet cemeteries in England, it emerged as news in 2010 that in one village it was allowed to bury pets side by side with their owners at a cemetery meant for humans. West Lindsey District Council gave permission for the scheme because the local churchyard of St John the Baptist is, like many others in Britain, fast running out of space. The site will remain agricultural and wildlife will be encouraged. It is intended that, over time, it will turn into a small wood and orchard. A spokesman explained: "We have never heard of a burial ground like this before. It seems like a new but rather strange trend - people not wanting to be separated from their pets in death, that is. There are 19 pet cemeteries in 
England and Wales but so far none has been linked with human cemeteries" (Jarvis 2010).

With the emerging age of the Internet, pet cemeteries have moved to virtual reality along with final resting places for humans. If you Google the term "pet cemeteries", you find interesting information about real as well as virtual pet cemeteries in Great Britain (The Assocciation 2016), America (Road Side Cemetery 1996-2017, A bit of Heaven Pet Cemetry; Los Angeles Pet Memorial Park \& Crematorium 2017). The International Association of Pet Cemeteries (IAOPCC) was founded in 1971 in West Chicago by Pat Blosser. Member pet cemeteries are expected to maintain the highest business and ethical standards. IAOPCC operates on a budget that is supported only by dues and other contributions from members. IAOPCC has no paid employees; all efforts are completely voluntary (IAOPCC 2017). The PDSA Pet Cemetery in Ilford (England) dates back to the 1920s and holds over 3,000 animals. In 2006 the cemetery was renovated, and where needed, headstones were restored or replaced. The garden provides quiet contemplation for all animal lovers. Hyde Park Pet Cemetery was established in 1880 at the back of Victoria Lodge. By 1893 there were 33 gravestones. The last burial was in 1967. Soldiers Dog Cemetery at Edinburgh Castle (Edinburgh, Scotland) is a small garden which has been used since the 1840s to bury the remains of officers' pet dogs as well as regimental mascots. America's oldest pet cemetery was founded in 1896. Dr Samuel Johnson, a veterinarian, offered his apple orchard to serve as a burial plot for a bereaved friend's dog. That single act of compassion marked the establishment of a beautiful hillside cemetery. Now a century later it is the resting place for over 70,000 pets. It also houses the War Dog Memorial, erected in 1923 for canines who served in the military. Los Angeles Pet Memorial Park, set in ten landscaped acres, is the final resting place for over 40,000 animals. The park was founded on 4 September, 1928. The Zoo Pet Cemetery is the most famous pet cemetery in Lisbon and is situated on a terraced hillside inside the zoo grounds for local people to bury their beloved pets. There are many tombstones here, mainly white marble, dedicated to pets. Central Park Pet Cemetery in Helsinki was opened in 1947. There are 3000 small graves of pet animals such as dogs and cats. Larger dogs and pets are cremated, 
their remains placed in urns. A charming aspect of this cemetery is the free-standing lanterns on individual gravestones, which makes the cemetery pleasant for after-dark visits (Pet Cemeteries throughout the World 2006). Post-socialist countries' pet cemeteries were founded later, after the collapse of the Soviet regime. Pietni Park Drahan, a pet cemetery in Prague, was founded in 1998 in the Bohnice neighbourhood of Prague 8. It is part botanical garden and part pet cemetery, holding 2,000 graves, and is a beautiful, calm place created with no concrete nor asphalt. Each owner can choose a tree or ornamental bush to be planted on their pet's grave. Interred here, for example, are former presidents Vaclav Havel's schnauzer and Jiri Paroubek's basset hound. Moscow Pet Cemetery was opened 24 August 2007. In response to demand, Moscow city government and private investors opened a pet hotel, veterinary clinic, visitor centre and Moscow's first pet cemetery. The centre stands on two hectares of land with space for 30,000 pets. The pet cemetery has proved very popular with Russian pet owners and many have sought its service. Cats, dogs, horses, parrots and even hamsters have found their last resting place amongst its hand-carved tombstones. Latvia Pet Cemetery is a woodland cemetery and the final resting place where dogs, cats, rats, birds, rabbits and fish all lie next to each other in harmony. There is a striking large central monument of a pet's collar, which was placed in memory of all lost animals gone to "other hunting grounds" The entrance is an imposing artistic and distinctive archway. The first and oldest pet cemetery in Poland opened in 1991. It gave Polish pet owners the chance to give their pets a dignified and lasting burial place. It is in a beautiful woodland setting. Transport to the cemetery for the animal can be arranged (Pet Cemeteries throughout the World 2006).

\section{Pet cemeteries in Estonia}

Historically, (pet) animal burials are nothing new in Estonia. Here Viking Age mounds have been found to include dog burials (Jonuks 2006) and the marked graves of local Baltic German pets (dogs, horses) have become a part of Estonian culture and folklore (Torp-Kõivupuu 2004). However, pedigreed dogs and horses of local mansion owners were privileged. Many of them were buried more nicely than the poor local peasants. The Estonian Folklore Archives 
contain texts that indicate that Baltic German barons and ladies buried their grand pets in mansion parks. Many of these pets have glorious pillars on their mounds which have, over time, enriched the local folktale tradition, describing the quirks of the mansion owners and influencing the local customs up to modern times:

The baron of Kiltsi Manor had a big white dog and it died and is buried to the garden of Kiltsi Castle. There is a large sharp rock on the grave in the mansion park even now. Some people wonder about the function of this pillar. It is nothing other than a grave for a dog. RKM II 336, 368 (4) < Väike-Maarja parish, Nõmme village - M. Hiiemäe < S. Tammistu (1979).

Based on the oral notes of Ell Vahtramäe from the expedition of 2003 to Väike-Maarja Parish, the grave of the dog at Kiltsi Manor has also shaped the local customs - allegedly local students took flowers there in Soviet times and later after their graduation.

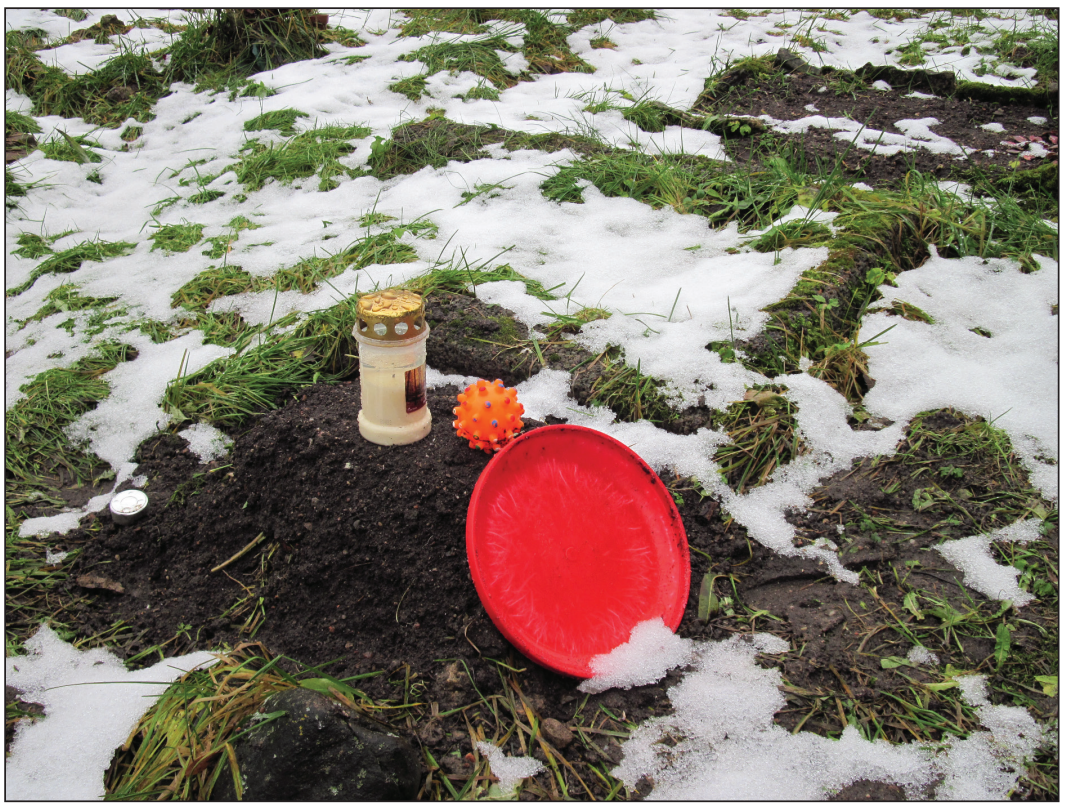

All photos taken at Jõelähtme pet cemetary, November 2011. Photos by M. Kõivupuu. 


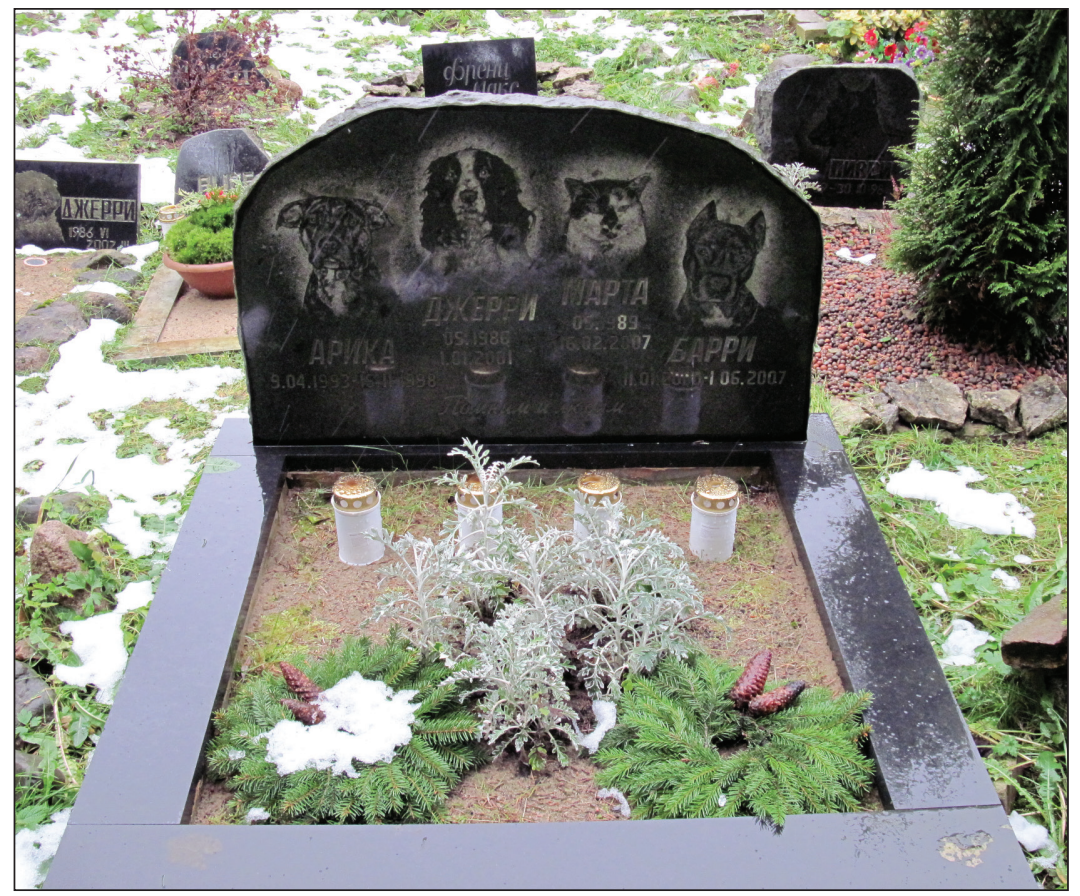

Grave pillars for pets that have survived to modern times are introduced today as significant local tourist attractions, and information as well as photos about them can be found on county websites. One of the best known dog graves in Estonia is located at the park of Koluvere (Kolovere) Castle (see Läänemaa: http://www./ekaart/ Laanemaa.html). On this website it is possible to find an e-card with the image of a grave pillar erected for a dog which may be forwarded to other people.

The Kõpu Manor park has a stone with crosses under which is the grave for the dog of the local manor owner. Harku Manor was owned by Friederih Vilhelm von Weymarn from 1895 to 1907 . He did not personally live in the manor. However, he did occasionally visit the general's madam there, and this madam had a riding horse called Ataman. When the horse died, it was buried in the manor park and a monument was erected on the grave, which included the phrase "holy mound". These words are visible even today. Later 
folk tales attempted to link this site with the novel Avenger (first published in 1880) written by Eduard Bornhöhe, claiming that the Avenger's horse or even the golden sword was buried there (Rahno 1965). Also an obelisk located in Tallinn at Glehni Park marks the grave of the favourite horse of Nikolai von Glehn (Kõrv 2006). The engraved commemoration plate is now missing from the obelisk and therefore it is an "empty" artefact for a person who does not know cultural history.

In Estonia we can speak about modern pet culture, including the burial customs and cemetery culture, only from the 1990s. The first animal cemetery in Estonia was founded in 1995 at Jõelähtme as a private enterprise. Post-socialist countries as well as our northern neighbours followed the lead (Torp-Kõivupuu 2004).

I visited this cemetery for the first time at the end of 1990s. Its uniqueness felt strange and even somewhat estranging for me. I had never visited an animal cemetery before, and the general picture was too similar to regular Estonian so-called "forest cemeteries" for me. Maybe the estrangement was fortified by the fact that I had

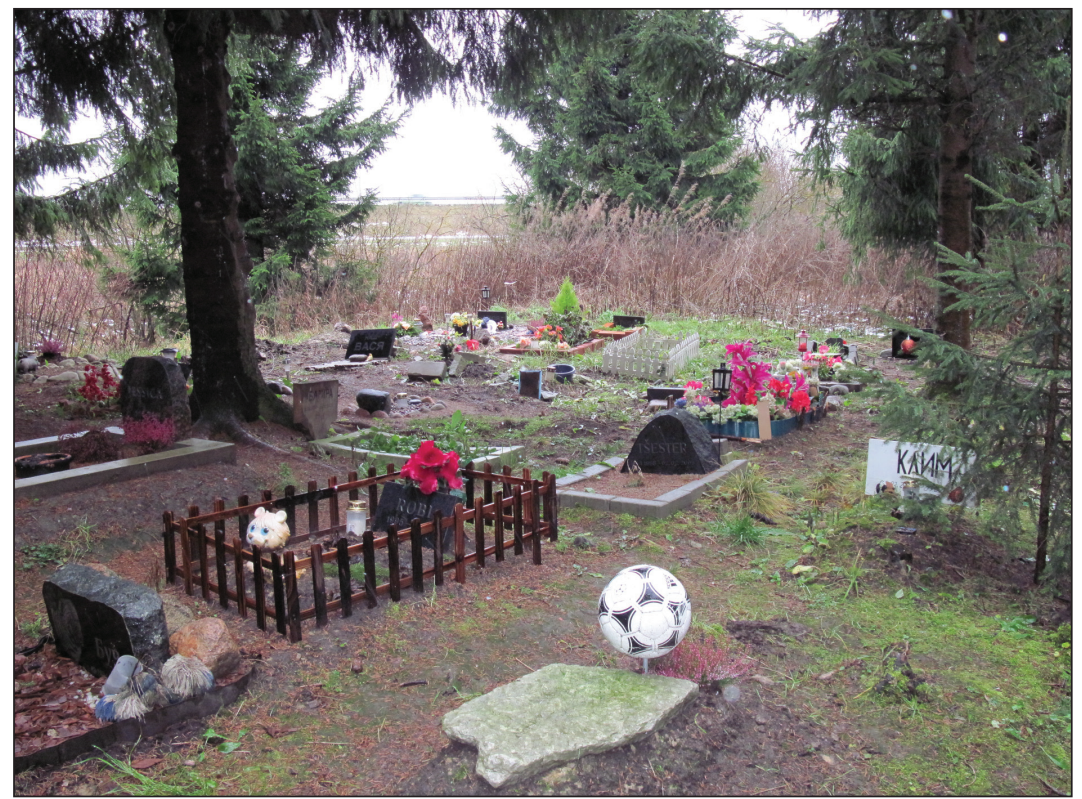


not acknowledged that modern pet culture with all its Western and cosmopolitan developments (along with many other European and so-called other-worldly phenomena) was trying to find its place in post-socialist Estonian society. As a rather new and marginal phenomenon, the burial customs of animals and their cemetery culture had received the attention of the print (yellow) press (Olvet 1999, Suviste 2000, Kiiler 2002).

The idea for a pet cemetery was initiated in 1994 by a veterinarian of the former Kostivere Sovkhoz called Enno Kosk, who in turn got the idea when visiting a pet cemetery in Canada. Harju II Lions Club helped in founding Jõelähtme Pet Cemetery, and it is managed by a retired veterinarian named Tiit Truumaa. According to the manager of the cemetery, the force behind its founding was the ever increasing cruelty and carelessness in human society - years ago some people picking mushrooms found some unidentified human bodies that were wrapped in white sheets and drowned like kittens, rocks tied to their feet (also Lepassalu \& Palli 2000: 39-40).

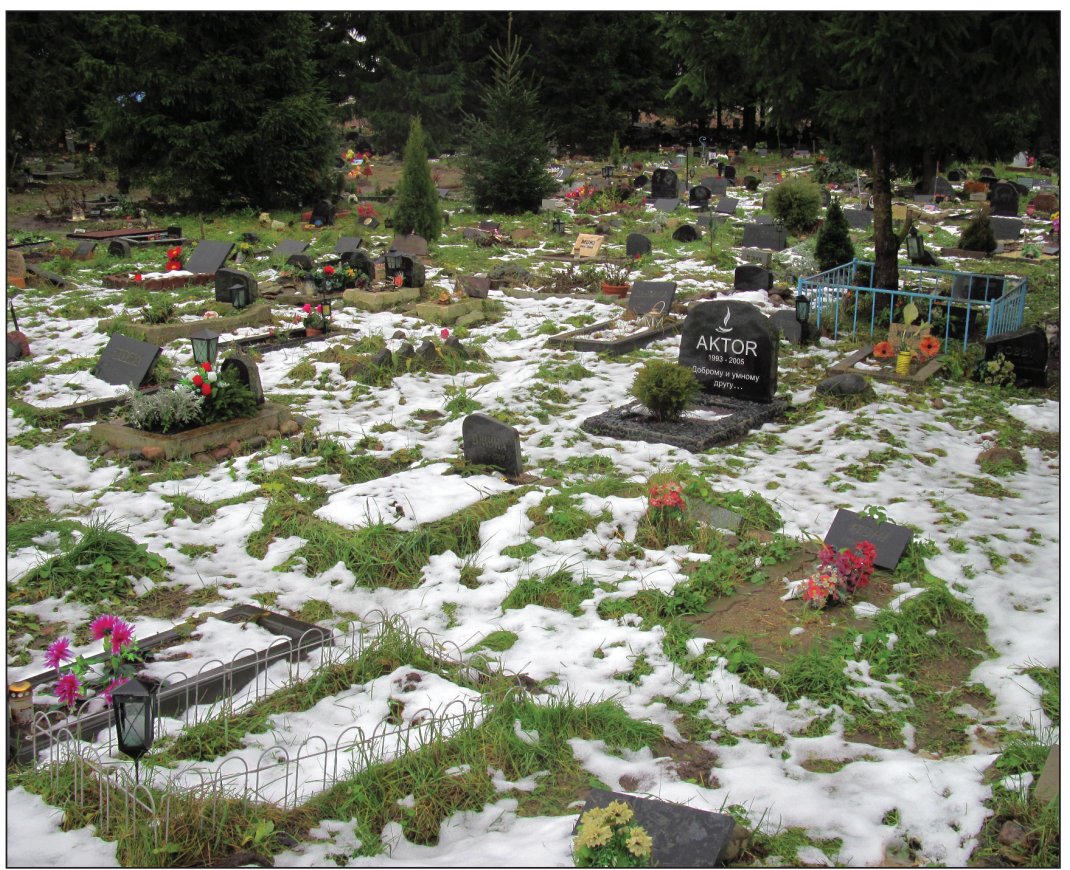




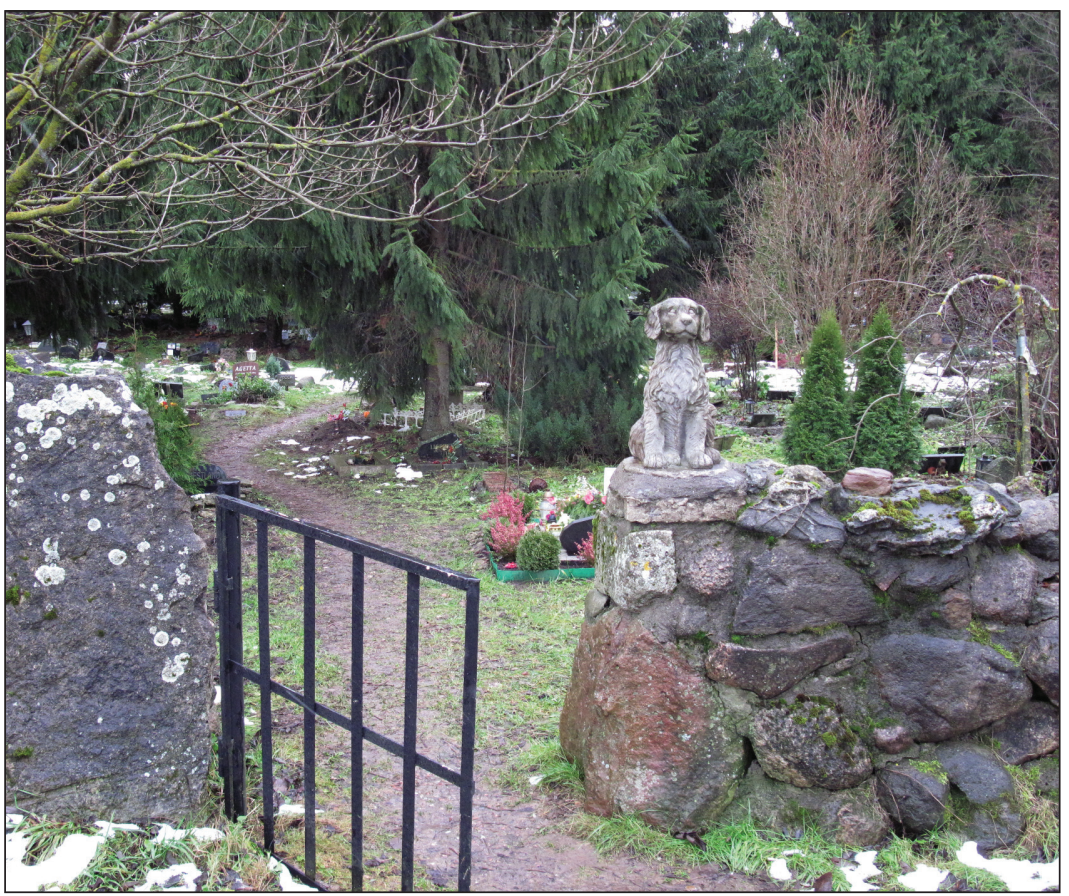

"If people are executed like animals, then animals should be buried like humans," said Truumaa. He believes that humans will become more humane by burying animals with dignity.

From that time burial places for pets have also been founded in other cities and towns. Valga Pet Cemetery was founded on town property in 2000 with initiative from the city government. It was first among the cemeteries fully financed by the city. The chief veterinarian of Valga Veterinary Office Jaan Luha said back then that if people were charged for this service then they would give up using the pet cemetery due to their financial limitations. Luha explained that there was a purely practical need for the cemetery: dead animals were dumped into garbage containers or in random places. Although Valga is a typical small town with many private cottages, people there do not always have the option to bury their pets - not all have cottages or private plots of land. ${ }^{5}$ The Rakvere pet burial ground was founded a couple of years back to Kullaaru 


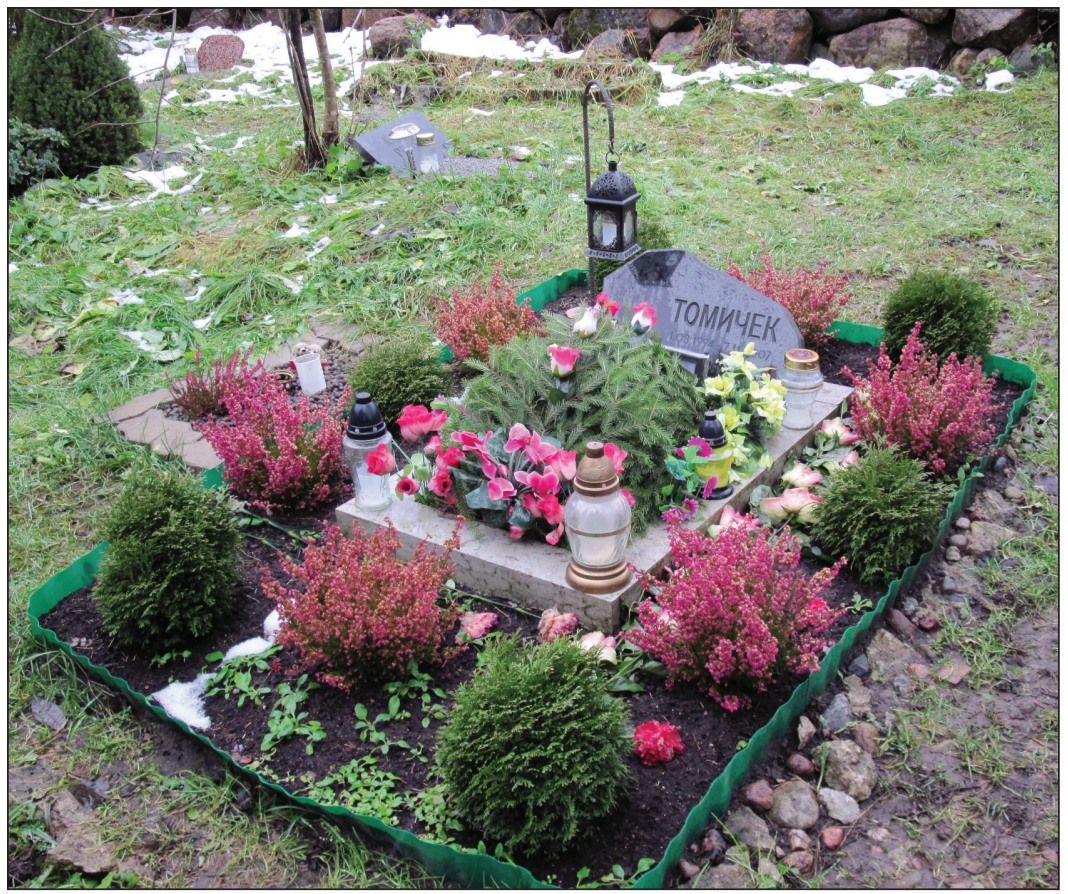

by the initiative of the local government and Elfriede Sillapere, the head of the local dog shelter, who found it unacceptable that pets who were put to rest or died were dumped in the landfill, where they lay for several days before being pushed into the general garbage by a bulldozer (Torp-Kõivupuu 2004). This is due to the socio-political and cultural changes which accompanied the restoration of independence. Therefore, it is a relatively new and still seemingly strange phenomenon, although now there is a real need for pet cemeteries in Estonian society. According to current legislation, the corpses of cats, dogs, mice, rabbits and other household pets are not considered municipal waste and it is not permitted to dispose of them in or next to municipal waste containers, nor is it allowed to put them somewhere else. ${ }^{6}$

I have faced the burial problem twice. There should be a pet cemetery in Pärnu, which could look like a nice park. In my opinion, it could be an additional activity for an entrepre- 


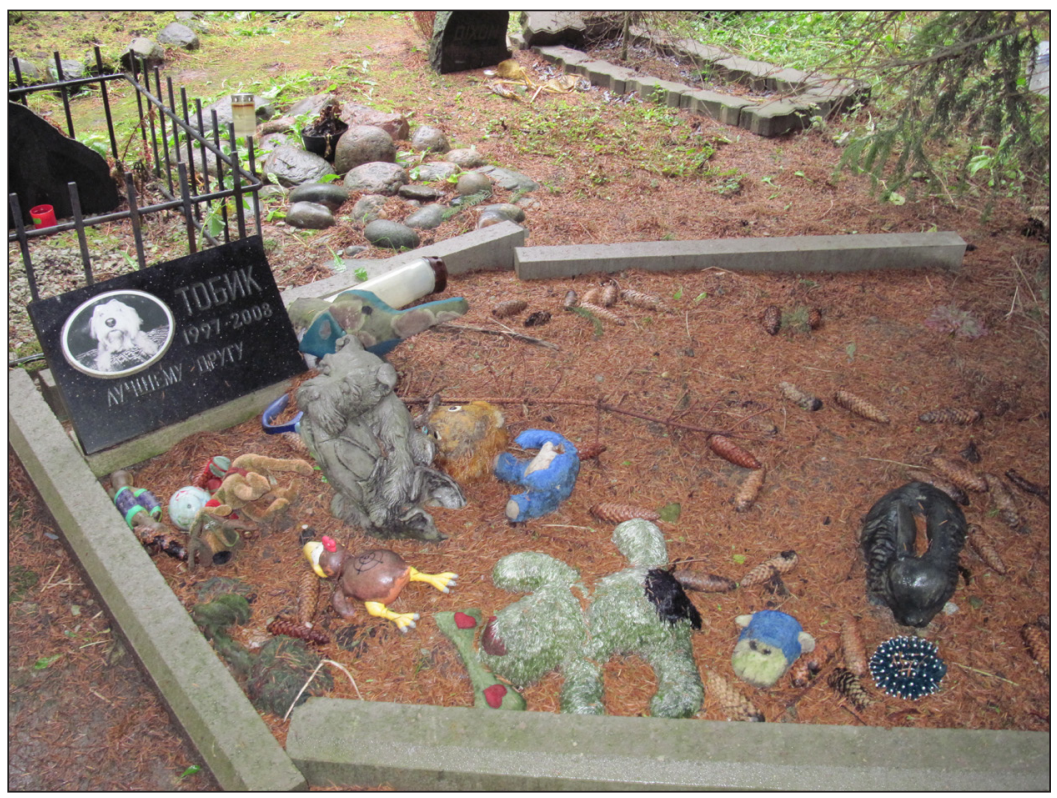

neurial person. However, I would like to see a person who takes their pet to one of those waste disposal factories. I would like to see this person for a moment and then never see them again (Naaber 2006).

I ask from people here - if there is an accident with your cat or dog or the animal has died for some other reason, how do you organize everything? Have you buried the animal nicely by yourself, taken it to the pet cemetery or, like it is done too often, dumped it in the forest or garbage container? I am asking because, when my old mother buried her dog, who was like family for her, in her garden, planted flowers on the mound and lit a candle, most passersby laughed - they thought the old hag was crazy... What have you done with your deceased pets? (Kassisõprade foorum, 2628).

We have buried them nicely in the garden, under the plum trees. Usually we have used a stone to mark the spot. Me and my mother buried my childhood friend, the Labrador-like dog 
Reti in his favourite place. It was winter and very cold outside. It seems somehow right to send pets to their last journey worthily. They lived and stayed with us. We had many experiences with them, talked to them, complained, were happy and many other things... They just are worthy of it. (Kassisõprade foorum, 2628).

In our summer house garden there are graves for a rabbit, hamster, dog and one tragically killed hornet (drowned in yoghurt) and I do not imagine walking with a dog (cat, rabbit) in a bag to cremate it somewhere or whatever. I agree with the fact that if someone does not have a garden there is going to be a problem with the burial and cemeteries are necessary (Kivi 2009).

A pet grows to become a family member. Always. Unfortunately, every animal, like every human being, has to die someday. Burying a pet is complicated because they can only be buried in special cemeteries. There isn't a pet cemetery in Pärnu. In real

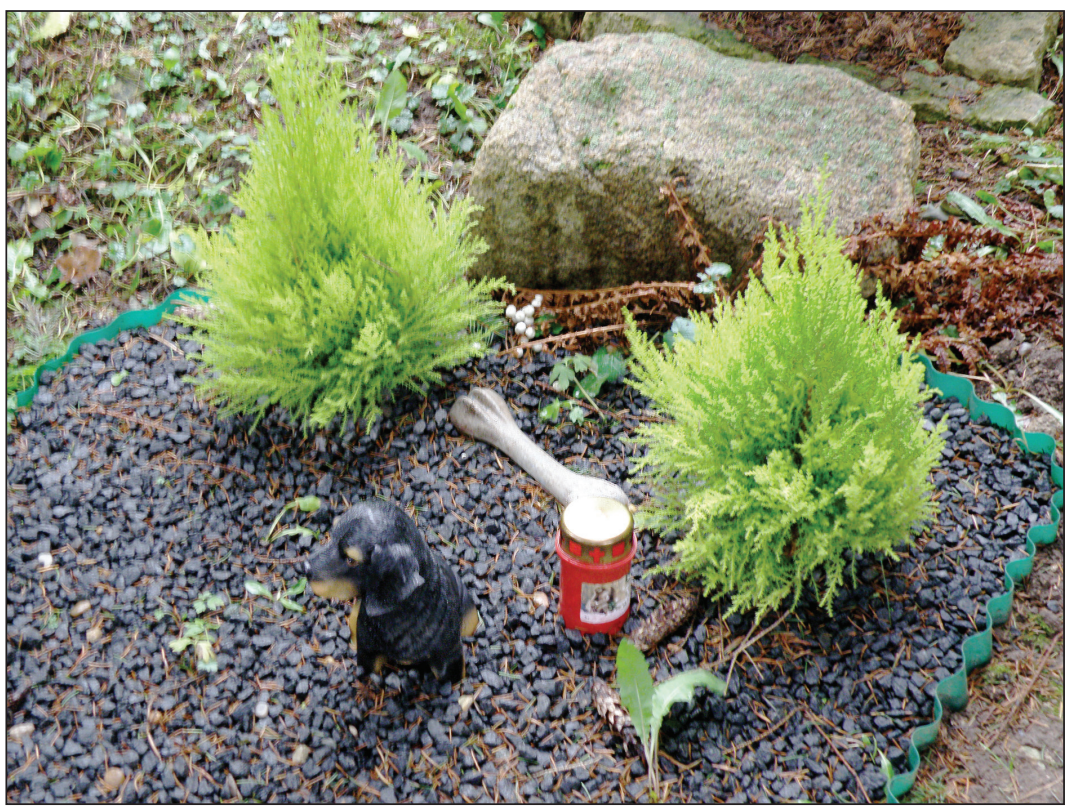




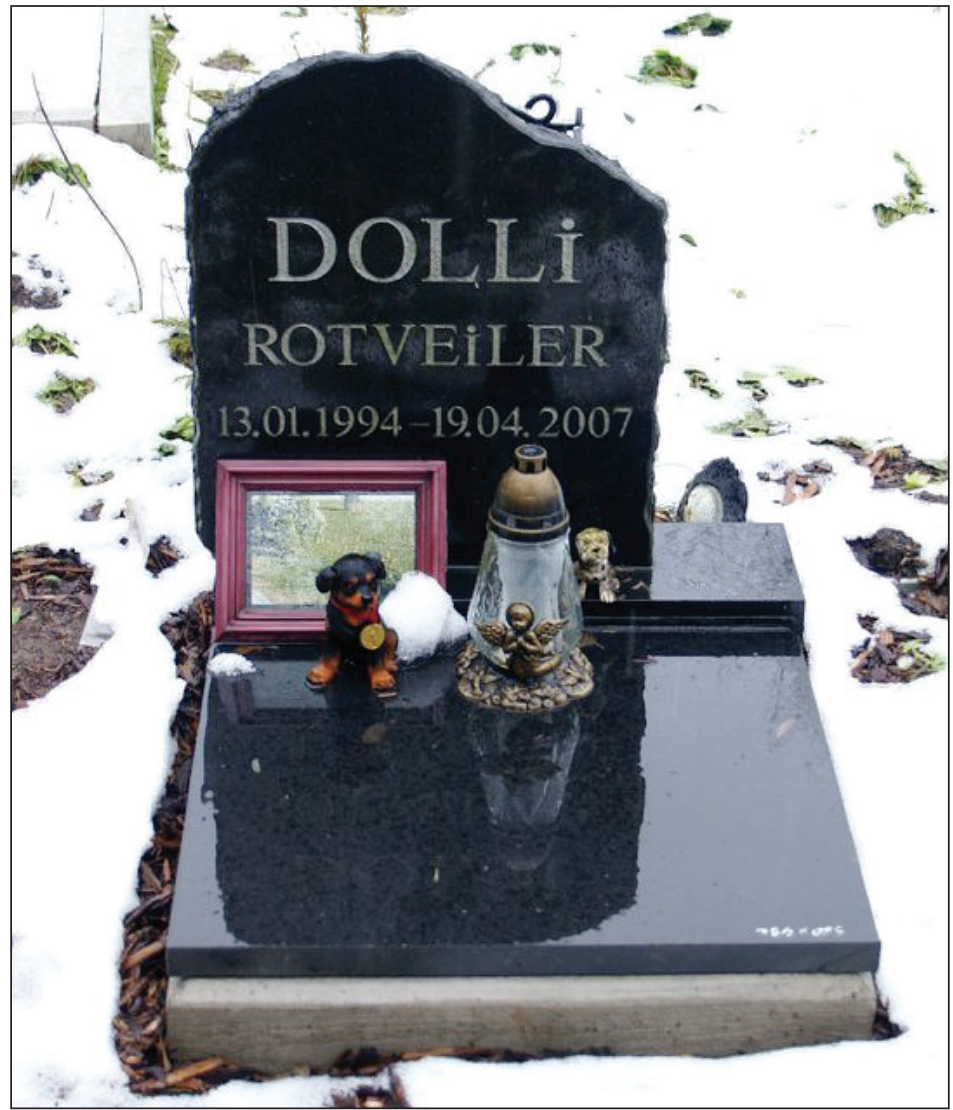

life, however, pets have always been buried and are going to be buried in gardens and woods, regardless of the forbidding legislation. Few people go to Viljandi or Tallinn to put their pet to rest. In those cities there are official pet cemeteries and it is possible to order a commemoration ceremony (Naaber 2006).

The pet cemetery planned in Kudjape on the island Saaremaa caused a fierce public discussion in 2009 because officials and heritage protection society thought that the pet cemetery was located too close to the human cemetery, which did not seem moral to them. Local people, however, though otherwise for the most part: 


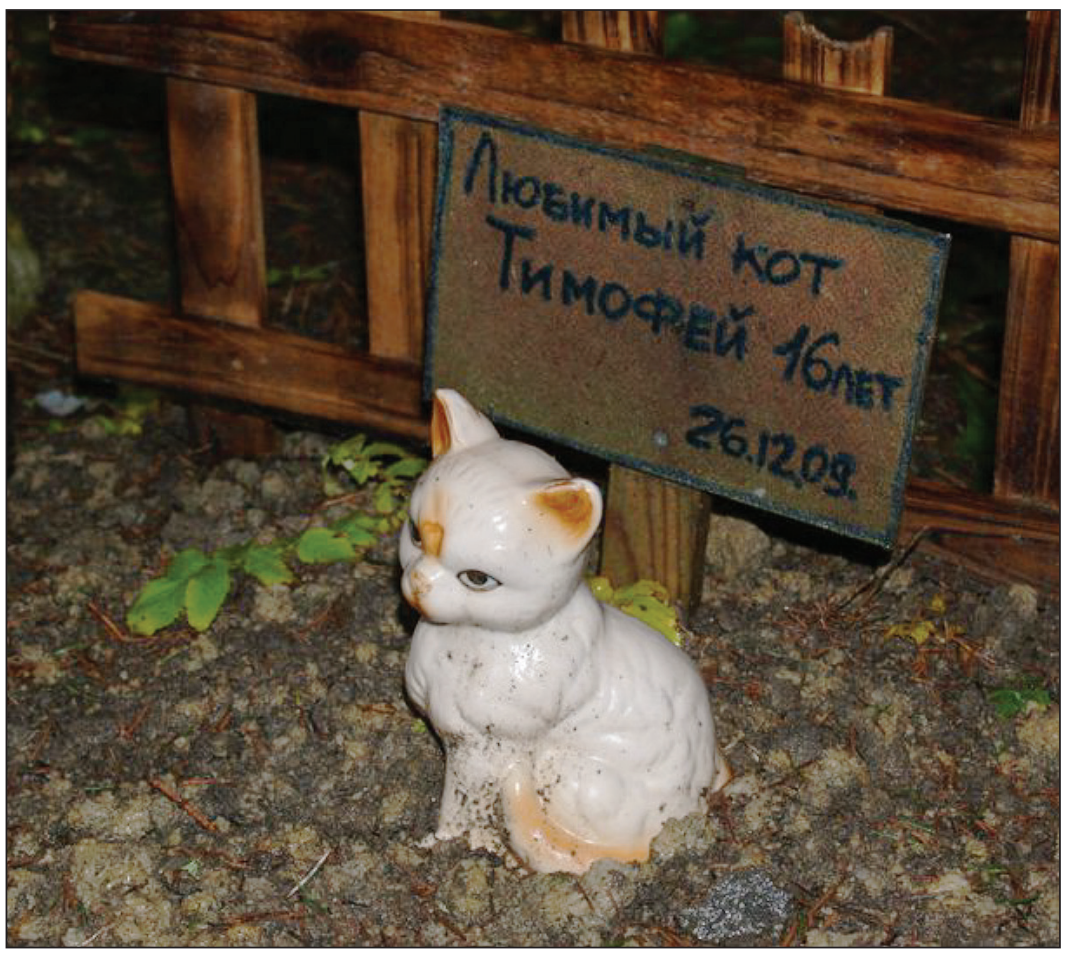

People want to be better even in death. A body is a body. In my opinion, burying animals close to their owners is a very nice idea. We will meet on the other side anyway (http://www. meiemaa.ee/index.php?content=artiklid\&sub=1\&artid=2842 $3,01.05 .2010)$

Cynical folk! How is it unethical? How is it not of culture? Where should they be buried if not in a separate burial ground? Is it ethical and cultural to leave an animal carcass lying around by a dumpster? (as I have no idea how an animal carcass should be categorized - it is not compost nor is it packaging...) Just wonderful how nice people have taken up the decision-making... heartless, I say (Kivi 2009).

Yes, but where should we bury the animals then? There are two or three pet cemeteries in Estonia and that is not normal. 
And all city governments think that such places are not necessary. Real life, however, shows the exact opposite. (Kivi 2009).

The compilers of the plan said that the plot meant for the pet cemetery was purposefully located close to the human cemetery because the plot was not suitable for anything else and the plan include a road to separate the pet cemetery from the human burial ground. After discussions among locals as well as in spoken and written media the plan was finally approved in its original form (Loel 2009, Kivi 2009).

The detailed plan of Võru city government has foreseen the founding of a pet cemetery, which would be located next to the human burial ground. According to the chief architect of the town, Ü. Eljand, the pet cemetery is a part of a cultural society where no one wants to throw their dead pet in the garbage and all people do not have a place for burying their pet (Tarbija24).

In the 1980s my daughter's friend's bird died. I think it was a canary. It died in the middle of the winter, so it was impossible to bury. The body of this birdy was kept in deep freeze for months and buried in Rahumäe Cemetery in the family's burial plot in the spring. I have also heard about pets being buried near windows, between bushes or under balconies. A couple of years ago my little friend's hamster died. [---] The animal was buried behind a large five-story building below its home window. The children, along with their friends, burned candles on the grave for days and put flowers there. (Oral note to Marju Kõivupuu < woman, b 1955, May 2004).

Regardless of the existence official pet cemeteries, there are always independent pet cemeteries in bigger cities, like at Iru or Pikakari beach in Tallinn (Linnaleht 2007). Pets have also been buried at the edges of cemeteries which were transformed into parks during Soviet times. In rural areas of Estonia burying pets is not a significant problem at the moment. According to interviews, among the inhabitants of Järvamaa County it is not common to cremate or bury a pet in a special pet cemetery. Fifty-six of the people who were interviewed said they would bury their pet in their garden or the garden of a friend or in the forest. Only two pet owners would get their pet cremated and two others would bury the pet in a pet 
cemetery. Fifteen pet owners did not know what they would do with their dead pets. It can be concluded that the topic is difficult and sad for the answerers. They would rather think about it when the day arrives (Vesik 2003).

We buried our dog in a quiet garden corner at our country house and ordered a headstone with the year of birth and death and name of the dog. It was, after all, our pet for a long 11 years. (Kassisõprade foorum 2628).

We briefly note that some people (mainly from a rural background) breed animals for profit. Other people (most of who are from urban societies) need pets as a missing link with nature or as friends/companions to relieve loneliness (see also Kruus 2004). And representatives of different nations and social groups hold different beliefs, convictions and attitudes towards (pet) animals and raising them.

\section{About the burial customs of pets}

Burial has been and is a very powerful and emotional event in every era and in every culture, be it for a human being or for an animal. In agrarian and/or village societies the attitude towards death has been one of the natural understanding of the perishable nature of life, in which the community has participated and received support through open rituals or some other way. This in turn has pacified people with death and tied them to burial traditions (Hyttinen 1996; Torp-Kõivupuu 2003; Pentikäinen 1990). However, in 1977 Philippe Ariès wrote that in modern Western death culture there is no place for dying. It has been distanced from everyday life and turned into a taboo. In developed societies death is mainly associated with the medical system, hospitals and various legal procedures - a world distant from everyday routine (Ariès 1977). Therefore, the Western world has once again begun discussing the possibility of "good death" in modern society - the right of a person to leave the home and relatives (Hyttinen 1996: 139).

In modern Estonia, however, there are still disagreements between medical personnel, private enterprises providing burial home services and the family of the deceased. The family feels that their rights are violated regarding family members who have died at hospices (the family is not notified about the death quickly enough; 
the family is not allowed to wash and clothe the deceased; a significant amount of money is charged for storage, etc.) (Päärt 2004: 9). The death of a pet does not seem to be as terrifying or tragic as the death of a human being. People may cry and feel sad when a pet dies, but sooner or later it is still possible to get a new four-legged friend (Hyttinen 1996: 139).

There have been quite many animals and birds in my life. We have buried them in the garden or the woods in the countryside. There have been no candles nor flowers. But it is not strange if someone wants to do it like that. Don't mind the laughing. I am especially sensitive and I have almost never participated in the funerals. My husband or friends have always taken care of the matter without me. I don't even know where exactly they buried the animals. I don't even want to think about that 1 . I focus on the living pets.(1) (Kassisõprade foorum).

Most children living in the countryside have buried and still bury their small pets and birds in a corner of the garden and decorate the mounds with flowers or small self-made crosses. This could be seen as the mechanical need to reflect the adult world. And such burial game is the first contact with death for the child, which helps to create understanding about the continuous cycle of life. Russian folklorist Sergei Borisov has considered the organizing of (pet) animal funerals a characteristic cultural phenomenon of children and teenagers, a ritual burial game (Borisov 2005).

In 1996 Sonja Hyttinen wrote in her article Muisto elää! (Hyttinen 1996: 138): "Today, animal funerals are not frowned upon any more. Some even consider them more important than human burials." However, as pet culture as a whole has existed from the inception of human culture, so have the ritual burial customs for them. It is not a characteristic - or a quirk, if you prefer - of modern urban society.

Burial customs for pets seem to be linked to the nationality and religion of the owners, and in general they copy the traditional burial customs of the corresponding ethnic group. Euthanasia is an inseparable part of pet death culture. Veterinarian and manager of the Jõelähtme Pet Cemetery Tiit Truumaa provides the service because he considers it humane: if life has become torture for the 
animal, then it is more humane to end its misery with an injection (Suviste 2000; Pet Cemeteries throughout the World 2006).

The general picture of Jõelähtme Pet Cemetery is of a typical forest cemetery: small grave plots are surrounded mainly by fir trees, a willow alley leads to the cemetery and ashes grow in one corner of the cemetery. Decorative broadleaf and conifer trees have been planted on the plots by their owners. Grave stones have also been designed according to the financial capacity of the owners. More luxurious, costing up to 9000 EEK, according to Truumaa, are pillars made of black marble with the pet's picture, its name, dates of birth and death, and more rarely engraved epitaphs (Loving you forever; We will not forget you, etc.).

At the owner's request, grave stones for pets at Jõelähtme Cemetery can be ordered from the stonecutters of Liiva Cemetery in Tallinn. These stonecutters say that it is most difficult to engrave portraits of Persian cats because the former lack facial characteristics. At Jõelähtme it is also common to attach photos of the pet to the grave stones. Some pet graves are decorated by crude natural stones which have surfaced when digging the grave and the structures of which require some fantasy to recall the dead pet. Even a piece of granite with an image of snakes has been found. And the grave stone for a dog of a lonely elderly woman recalls a grieving woman at a certain angle. It is also possible to order a grave stone at Rakvere Pet Cemetery (Kiiler 2002).

It is significant that many pet graves are decorated with crosses or the sign of the cross has been engraved on the grave stone. For example, at Valga Pet Cemetery there is a black wooden cross on the grave of a dog, which seems to have been bought from a burial office meant for humans. However, Truumaa says that priests claim that some pets are even baptised, which allegedly permits the use Christian symbols (the sign of the cross in this case) on pet graves (Tiit Truumaa to Marju Kõivupuu 2001). The use of crosses and other Christian symbols at Estonian pet cemeteries is still widespread.

At Helsinki Pet Cemetery the most popular Christian symbol is supposed to be the image of an angel. The Star of David and the cross are not generally used in Finnish pet cemetery culture (Hyttinen 1996: 151). When visiting Jõelähtme Pet Cemetery during Easter 
2004, I had to admit that the image of an angel is also increasing in popularity among Estonian pet owners. There was a note in the recommendations written for the users of Jõelähtme Pet Cemetery that it is not recommended to use a sign of a cross as a grave marker at Jõelähtme Pet Cemetery.

The general picture of the grave plots also offers information about the financial status, aesthetic taste, and beliefs of pet owners - the financially better-off ones can afford luxurious fences (cast border or a metal fence), decorative flowers for the grave and in some cases even a bench for sitting. In the case of owners with a more mediocre budget there are semi-natural decorative plants on the grave and a bland concrete slab or a wooden board, if even that, with the name of the pet and its years written by hand.

A pet owner can order a funeral ceremony from Truumaa if desired. There is a separate room for that purpose where a candle is lit next to the coffin placed on a table covered with black linen, and a short ceremony is held. Once he even played funeral tunes on his harmonica. It was possible to buy cardboard coffins onsite. Those were manufactured by a nearby small enterprise producing cardboard boxes and other packaging.

Hello! I am new to this forum and I have a problem. I am studying product design at the Estonian Academy of Arts. In cooperation with the paper factory of Räpina we have a project in which we have to generate new and interesting products for the company. I proposed the idea of coffins for pets. However, I cannot develop a definite design as one of the lecturers raised the question of the necessity of such products and their sales. So my question is: if pet stores or stores related to burials were to sell paper coffins with a cute appearance, would someone buy them? The Räpina factory recycles paper and produces paper, and the material is generally rather thick (not typical copy machine paper, but paper with the thickness of 0.5-1 $\mathrm{mm}$, and it is possible to use supporting profile corners with the thickness of many millimetres). Please help me. The lecturer has never had any pets and therefore it is impossible for that person to have sufficient grasp of the field. However, the lecturer managed to convince the representative of the company that the idea is stupid. In addition, could you please provide 
information about good pet stores in Tallinn: which ones do you prefer, which have a good selection of products, their locations, etc.? (Pisiloomade netipesa 2005).

However, this enterprise moved to Tallinn, and now many pets are buried "as God created them". Truumaa holds views quite similar to natural religion and he considers it right for the pet to be buried without a coffin or in a coffin as nature friendly as possible, which decomposes easily (see also Lepassalu \& Palli 2000: 40).

Allegedly, owners have wanted to bury their pets in plastic bags and oak coffins. One woman had said that if her father and mother had oak coffins, then why shouldn't the dog, who is also a family member? Russian men in black t-shirts, golden chains and leather jackets have been seen burying their dogs rolled into a leather jacket (Olvet 1999).

People reportedly often come to pet funerals with many cars with relatives, friends, acquaintances and colleagues. Truumaa says that Russians have the custom of organizing a picnic after the funeral ceremony near the cemetery during the summer:

Today they brought a pooch from Kohtla-Järve, shed a tear and a little rum was passed around. Like the custom is (Lepassalu \& Palli 2000: 38).

Estonians are characterized by individuality - after the ceremony the owner walks around alone, head down, avoiding interaction with others. The fresh graves are decorated like they are for humans, with flowers and wreaths, the amount and size of which depend on financial limitations. Although it is customary for some pet owners to add some food for their deceased companion to eat during the journey to the other side (Mikkor 2000: 153), Truumaa says that the clients of Jõelähtme Cemetery do not follow this practice. However, there are numerous traces of sacrificial customs on the mounds. There are leashes of cats and dogs, their favourite toys, feeding bowls and other emotionally dear minor objects which are somehow linked to the deceased pet. During holidays, especially during Christmas, candles are lit on the graves. Some have even brought a tiny Christmas tree to the grave and decorated it or decorated the branches of a fir tree growing next to the grave. Food is also brought to the graves - candies, gingerbread, bones, or the 
favourite type of pet food, mostly around Christmas and New Year's. Orthodox Christians place coloured eggs during Easter onto the graves of the "small brothers". Allegedly, it is not uncommon for Russians to drink vodka and eat on the graves during church and calendar holidays. Food sacrifices are also brought to commemorate the dates of birth and death of pets. In addition, it is customary, but of course dependant on the season, to clean the graves, bring/ plant flowers or commemorate the deceased pet in some other way on those dates.

When compared to human graves, pet graves are designed more creatively - the favourite objects of furry friends are not put inside the graves; they are left on the mound. So the grave marker is not necessarily a stone or a cross but maybe a bucket or a toy which the animal liked during its lifetime.

At Valga Cemetery there have not been any significant burial ceremonies for pets so far. In the case of burial in a mass grave there is a ditch dug by a tractor at the back of the cemetery. Stray animals and most domestic pets are buried there. Unfortunately, a half-finished mass grave is not an aesthetic experience, especially during the spring when the snow is melting. When the ditch fills up, the tractor covers it with earth, it is made even and that completes the whole ceremony (Marju Kõivupuu's interviews with Jaan Luht and Endel Rebane in 2002 and an expedition to the cemetery in spring 2004).

In 2004 a charity concert took place in Tallinn to gather money for purchasing a pet cremation oven and creating a commemoration wall - Jõelähtme Pet Cemetery located close to Tallinn is no longer able to fulfil the needs of all animal owners.

Truumaa has some religion-oriented stories about a few pets buried at the cemetery. According to Truuma, paying too much attention to a pet can be bad for human fertility. Allegedly, a Russian young couple had been living together for four or five years but they did not have any children. There was no medical explanation - the young people were healthy. They even considered adopting a child. But then the family's pet cat Oskar, who had so far received all the attention, died. And a couple of months after the cat's funeral the woman became pregnant and gave birth to a healthy child (also Lepassalu \& Palli 2000: 40). Another dog owner erected a pyramid- 
like black granite grave pillar saying that the pillar continues to radiate the positive energy of the deceased dog, which helps the master to maintain emotional balance and good health.

\section{Conclusion}

And over the river of eternity

I build a bridge for thee

Only for thee a bridge over the river of eternity...

(To Corli: Dog no. 4/2003:23)

The traditional beliefs of different peoples claim that the rainbow is a bridge that leads to the afterlife from the world of the living. The same saying is used by many pet owners today when they talk about their deceased four-legged friend.

Pet cemeteries and memorials can be found throughout the world. Many date back hundreds of years and some are more recent, but they are all a touching tribute to humans' bond with their unique and beloved pets and can be places for quiet contemplation. Some animal lovers enjoy visiting pet cemeteries, walking around the graves and reading the headstones with their poignant words. This can be very comforting and therapeutic. They say it gives them inner strength (Pet Cemeteries throughout the World 2006.)

Although the practical need for pet cemeteries in an urban cultural space is understood in modern Estonia, the pet cemetery culture still seems strange for many people because of the practice of holding extremely luxurious and nice pet funerals. The fact is that in post-socialist Estonia the quality of life for many people, including children, does not reach that of (pedigreed) pets and burials for not only marginalized people, but for working-class people as well, do not often receive as much attention as those for pedigreed dogs and cats. The aforementioned is probably the reason why the funeral customs part of the pet culture has received ironic attention from the press: the clients of pet cemeteries are depicted as strange people who only have passion towards animals (Lepassalu \& Palli 2000: $38,40)$. The equating of animals and humans through the burial ritual and grave cult was derogated in articles during the first years of pet cemetery culture (Lepassalu \& Palli 2000). Members 
of Harju county Lions Club also had to acknowledge a suspicious attitude towards supporting the pet cemetery: During the opening it was doubted whether pets deserve that much respect. However, we cannot support everybody (Lepassalu \& Palli 2000: 41).

If in Europe and the United States the discussion topic is whether pets and humans can be buried in the same cemetery, then in Estonia the idea to plan a pet cemetery too close to a human cemetery still causes strong backlashes. The pet cemetery located at Jõelähtme has tripled its territory during its 15 years of activity, and there is not much space left for further expansion. Independent burial sites for animals have formed on wastelands and beaches in Tallinn, which shows that in cities the need for pet cemeteries exists.

People living in the countryside or in private houses (mostly Estonians) bury their pets in the yard or on their property:

Do you have a cemetery for your pets at home? If not, then where do you bury your deceased pets? We have a place under our birches where all the pets of our family have found their final resting place for decades.

We have a real cemetery at our country house.

Those buried there include the cats Blanche and Vanku, the dogs Tuti, Nelli and Ferdinand, 5 rats if I am not mistaken and countless number of birds and moles, which the animals have killed. I don't know, I would not bury my animal in the pet cemetery. However, if I could not bury them in the countryside, then I guess I would have no other choice. (United cats. Foorum).

Based on the burial customs for pets it can be concluded that anthropomorphism is not new for a large part of society, including Estonian pet owners. Pets have been depicted as reflections of humans, like God once created man according to his own image. A person has to decide how to bury their pet - whether to dig a simple hole or send it to the land of rainbows with an orchestra, and mark the gravesite with a stone. The equation of animals with humans says a couple of words about the values and the inner world of the person, argues psychologist Voldemar Kolga, and raises a number of rhetorical questions: Is it good to see the animal as human? Is there no difference between an animal and a human? Has the dog 
given permission for it to be dressed like a human, fed like a human and buried like a human (Kolga 2000: 41)?

As in other parts of the world, the burial customs and traditions for pets copy the burial customs of humans in Estonia. No significant new traditions or customs specific and only relating to pet cemetery culture have surfaced so far. If euphemistic expressions are used for a deceased person (left this world, went to walk the eternal path, left the earthly path, went to see how the potatoes grow on the other side, etc.), then pet owners have their own symbolic language for talking about deceased pets - this or that favourite doggy went beyond the rainbow or to the rainbow land. This figure of speech has probably been directly translated from usage in the Anglo-American cultural space but if we think about the ancient symbol of a rainbow as a bridge between the worlds of the living and the dead, which is common for many peoples, including Estonians, then the use of this figure of speech seems very appropriate.

Daily newspapers publish death notices and grieving messages when a person dies but there are certain magazines for pet owners (for example, the Estonian Kennel Union magazine Koer and the Tartu Sheepdog Breeders Union magazine Uran), which publish obituaries for dogs, death notices and condolences to owners upon losing their four-legged friends. As a new tradition, Cemetery Day was first held at Jõelähtme Pet Cemetery on May 8, 2004, which was preceded by cooperative work in the morning - cleaning the cemetery and its surroundings.

If we compare Estonian pet cemetery culture with that of our northern neighbours, the Finns, then we find numerous similar customs and traditions (Hyttinen 1996), but there are also differences. For example, in Estonia it is not customary to write the pet owner's name on the grave marker, but allegedly it is present on the grave markers of Helsinki Pet Cemetery, which is, according to Sonja Hyttinen, a mark of the especially strong spiritual bond between the human and the pet (Hyttinen 1996). Although the visiting, cleaning and decorating of pet graves on (church) holidays is common in both Estonia and Finland, it can be concluded once again that there are detailed differences in that field. Compared to Finns, it is not very popular among Estonians (i.e. Lutherans) to visit the cemetery during the Easter holidays and decorate the graves with 
spring flowers and/or pussy willows. This custom is more often associated with Russian practice, which has its reflection in Estonian pet cemetery culture: Orthodox Christian pet owners take coloured eggs, candies, and pussy willows to the graves of their pets. This custom is certainly followed at Jõelähtme Pet Cemetery.

The main differences in pet cemetery and death culture seem to be based on the religious considerations of pet owners: Lutheran pet owners or people with a Lutheran background extend their traditions and customs to pet culture and the same goes for Orthodox Christians, nature believers and atheists. If in modern post-socialist and multicultural Estonian society, where religion is a historic phenomenon for many and the daily newspapers discuss whether religious education should be taught at schools, then, for example, the following was an important topic in Finland recently: "Do (pet) animals go to heaven or not?" (see Hyttinen 1996).

Unfortunately, there are no relevant socio-psychological and ethnological studies about the nationality, education level, religious beliefs, living conditions, income, pet species of pet owners to make deeper generalizations. Based on the rather scant data, I dare to say that the pet (cemetery) culture is more developed among the nonEstonian population in Estonia. Those people lack traditional village culture and their concentration is higher in (industrialized) towns.

The number of official pet cemeteries has increased in Estonia, implying that people also need the cemeteries in smaller, rural towns where the population mainly consists of Estonians. This is understandable because the life expectancy of pets is generally much shorter than that of their owners, and after its death the pet needs respectful handling. Psychologists recommend pets for families with children because the children have to learn and experience the eternal cycle of life and death from a very young age. For the proverb says: You only live once, and no one can escape death.

\section{Acknowledgements}

Financial support came from the European Union through the European Regional Development Fund (Centre of Excellence in Cultural Theory) and Estonian Ministry of Education target-financed project SF0130033s07 Landscape Practice and Heritage. 
Translated by Ester Eggert.

\section{Notes}

${ }^{1}$ In the Estonian climate it is necessary to dress some cold-sensitive breeds to protect them from rain and wind. People found that it was important for the pet to wear a reflector vest in the dark. Only five out of one hundred pet owners clothe their animals to protect the health of the pet; the rest did not consider it necessary. The participants were divided into two major groups according to their attitudes: those who thought well of or tolerated dressing pets and dressed their pets to protect their health; and those who did not favour the clothing and decoration of pets and considered it ridiculous and even torture for the animal. Külli-Kerttu Siplane, who wrote her master thesis about dressing animals and the clothing used, thought that dog clothes and jewellery have a market in Estonia, which is due to the changing dog culture.

${ }^{2}$ According to Focus magazine data, in 2004, the Germans had 22.2 million pets on their sofas and in their front yards. 2.7 billion euros is spent annually on food, housing and appliances for 6.9 million cats and 4.7 million dogs. As a token of gratitude, the dogs leave 40 tons of faeces on the streets of "the dog capital" Berlin every year (Koerad. 2004).

${ }^{3}$ I live in Tallinn in an apartment building with 80 flats. Most Russianspeaking families have at least one pet. Estonian families in the apartment building have fewer pets or none at all. As new inhabitants it was much easier to our family to blend in once our Russian neighbours discovered that we had cats. I have occasionally interviewed the non-Estonian students of Tallinn University about pets and according to them, Estonians are mostly rational, material and emotionless because they do not like pets. At the same time my relatives and friends from Southern Estonia cannot grasp the fact that I have cats in a city apartment because cats should stay outside; expenses for cats (food, litter, medical care) are classified under senseless spending.

${ }^{4}$ The most famous centre of the cat cult in Egypt was located in Bubastis in the delta of the Nile River. There was a red granite temple and a golden statue for the feline goddess Bast. Bubastis and other cult locations were dead cats were brought to be embalmed by priests. They were mostly placed in wooden receptacles covered with copper, bronze, silver, gold or colourful stones. The cat mummies were accompanied to the netherworld by a milk cup and embalmed mice. Many feline statues made from burnt clay, bronze, silver and even gold, which were given to temples to commemorate dead cats have survived to modern times. In Japan the cat is considered holy. 
In East Asia it is thought that cats bring good luck. In Islamic countries cats are considered clean and pure, and dogs impure. Orthodox Christians also think that cats are clean, but dogs are sinful. According to Bible tradition, a dog led the predators to the cave where the Virgin Mary hid with the infant Jesus.

${ }^{5}$ According to valid legislation, dead pets can be buried on an estate owned by the master of the pet, or if agreed in advance, also on property owned by someone else, at least $10 \mathrm{~m}$ from a dug well (http://www.maaleht.ee/news/ uudised/eestiuudised/article.php?id=23965667, 09.05.2010).

${ }^{6}$ If an animal has died, it is not called Sassy, Hamish or Daisy in the legal language. It is animal waste. The latter are divided into low-risk and highrisk waste according to how dangerous their remains are for the health of humans and animals. (Series 2009; http://www.maaleht.ee/news/uudised/ eestiuudised/article.php?id=23965667, 09.05. 2010).

\section{Interviews, archives}

Truumaa, Tiit 2001. Interview with Marju Kõivupuu. August.

Truumaa, Tiit 2002. Interview with Marju Kõivupuu. January.

Luht, Jaan 2002. Interview with Marju Kõivupuu. July.

Rebane, Endel 2002. Interview with Marju Kõivupuule. July.

Vahtramäe, Ell 2004. Oral reports to Marju Kõivupuu.

Vares, Viivika 2004. Interview with Marju Kõivupuu. May.

RKM - Manuscripts from Estonian Folklore Archives.

\section{References}

A Bit of Heaven Pet Cemetery 2016.

http://www.abitofheaven.com (Accessed 31.08.2017).

Ariès, Philippe 1977. L'homme devant la mort. Paris: Seuil.

Borissov Sergei B 2005. Pokhorony zhivotnykh kak fenomen detsko-podrstkovoi kul'turõ. Foklor i postfoklor: struktura, tipologia, semiotika. http://www.ruthenia.ru/foklore/borisov4.htm (Accessed 31.08.2017).

Hyttinen, Sonja 1996. "Muisto elää!": Lemmikeläimen kuolema ja hautamuistomerkit Helsingin eläinten hautausmaalla. Kinnunen, Eeva-Liisa 
\& Koski, Kaarina \& Penttilä, Riikka \& Pietilä, Minttu (eds.). Vitsistä videoon: Uusia kirjoituksia nykyperinteestä. Tietolipas, 146. Helsinki: Suomalaisen Kirjallisuuden Seura, pp. 137-155.

IAOPCC 2017. The International Association of Pet Cemeteries. http://www.iaopc.com/pageDisplay.jsp?pageid=12620 (Accessed 31.08.2017).

Ingold, Tim 2002. Humanity and animality. Ingold, Tim (ed.). Companion Encyclopedia of Anthropology. Routledge world reference. London \& New York: Routledge, pp 14-32.

Ilomäki, Henni 2002. Loomad rahva meeles ja rahvaluule keeles. Jaago, Tiiu \& Kõiva, Mare (eds.) Dialoog privaatse ja avaliku elu vahel:Inimese ja keskkonna suhete peegeldus pärimuses. Elektrooniline konverents: Täiendkoolituskursus. Tartu: Eesti Kirjandusmuuseum \& Tartu Ülikool, pp. 13-18. http://www.folklore.ee/rl/pubte/ee/cf/dialoog/teema1-2.pdf (Accessed 31.08.2017).

Jarvis, David 2010. Pet-lovers can be buried with their animals. Express. (01.24.2010)

http://www.express.co.uk/posts/view/153754/Pet-lovers-can-be-buried-withtheir-animals (Accessed 31.08.2017).

Jobes, Gertrude 1962. Dictionary of Mythology, Folklore and Symbols. New York: Scarecrow Press.

Jonuks, Tõnno 2006. Koerad Eesti asukate viikingiaja maailmapildis. Mäetagused, 31, pp. 29-48.

http://dx.doi.org/10.7592/MT2005.31.jonuks

Kaaristo, Maarja 2006. Vägivald loomade vastu: inimene ja koduloom LõunaEesti külas 19. sajandi teisel poolel vallakohtute protokollide näitel. Mäetagused, 31, pp. 49-62.

http://dx.doi.org/10.7592/MT2005.31.kaaristo

Kassisõprade foorum 2628.

http://www.kass.ee/viewthread.php?tid=2628 (05.05. 2010) (Accessed 31.08.2017).

Kiiler, Gert 2002. Rakvere lemmikloomakalmistul puhkavad kõrvuti krants ja tõukoer. Sakala (16.08.2002).

https://sakala.postimees.ee/2387409/rakvere-lemmikloomakalmistulpuhkavad-korvuti-krants-ja-toukoer (Accessed 31.08. 2017).

Kivi, Alver 2009. Saaremaa saab lemmikloomade kalmistu. Meie maa. (20.02.2009). 
http://www.meiemaa.ee/index.php?content=artiklid\&sub=1\&artid=2842 3 (Accessed 31.08.2017).

Koer 1998 (1); 2003 (4). Tallinn: Eesti Kennelliit.

Koerad 2004 = Suhe, mis aitab mõlemaid. Postimees. Arter. (07.02.2004) https://www.postimees.ee/1397331/suhe-mis-aitab-molemaid

Kõivupuu, Marju 2013. Ole sa loom või inimene... Looming, 6, pp. 868-871.

Kolga, Voldemar 2000. Inimeseloomad: Kommentaar [V. Lepassalu ja I. Palli artiklile "Olgu muld sulle kerge: Kadunukesed: Eestis maetakse mõningaid loomi nagu inimesi ja inimesi nagu loomi”]. Luup, 10 (119) (15.05.2000), p. 41.

Kõrv, Jaanus 2006. Nädala juubilar: NICOLAI von GLEHN 165. Kesknädal. http://www.kesknadal.ee/uudised?id=7433 (Accessed 31.08.2017).

Kruus, Tiina 2004. Minu pereja muud loomad. Eesti Naine, 4(April), pp. 32-35. http://www.eestinaine.ee/40707 (Accessed 31.08.2017).

Lepassalu, Virko \& Palli, Ilmar 2000. Olgu muld sulle kerge.Eestis maetakse mõningaid loomi nagu inimesi ja inimesi nagu loomi. Luup, 10 (119) (15.05.2000), pp. 38-41.

Lestel, Dominique 2002. Human/animal communications, language and evolution. Torop, Peeter \& Lotman, Mihhail \& Kull, Kalevi (eds.). Sign system studies = Tруды по знаковым системам = Töid märgisüsteemide alalt , 30 (1), pp. 201-212.

Lindgren, Astrid 1969, 1993, 2000. Väike Tjorven, Pootsman ja Mooses. Transl. Vladimir Beekman. Tallinn: Eesti Raamat.

Linnaleht 2007.

http://www.linnaleht.ee/frontpage/tln_ek/2007-04-04-b.pdf (Accessed 31.09.2017).

Loorits, Oskar 1990. Eesti rahvausundi maailmavaade. Tallinn: Perioodika.

Los Angeles Pet Memorial Park \& Crematorium 2017. S.O.P.H.I.E., Inc. https://www.calabasaspetcemetery.com (Accessed 31.08.2017).

Läänemaa. Everyday.com e-kaart. Teemagalerii. Eesti erinevad paigad. http://www./ekaart/Laanemaa.html (27.05.2004).

Mikkor, Marika 2000. Minu merisigade elust. Mäetagused, 15, pp. 152-158. https://dx.doi.org/10.7592/MT2000.15 
Naaber, Grete 2006. Kui koer on tõeline pereliige. Pärnu Postimees. http://parnu.postimees.ee/2129761/kui-koer-on-toeline-pereliige (Accessed 31.08.2017).

Nerman, Robert 1998. Lasnamäe ajalugu. Tallinn: Eesti Entsüklopeediakirjastus.

Olvet, Triin 1999. Loomakalmistu aitab hoida mälestust neljajalgsest sõbrast. Postimees (26.07.1999).

Pet Cemeteries throughout the World 2006. Pets4ever.org.uk.

http://www.pets4ever.org.uk/content.asp?cpage=Cemeteries (Accessed 30.08.2017).

Pet Memorials 2008. Popular Pet Cemeteries in Europe 2008. Peternity.com. http://www.peternity.com/pet-memorial-article/pet-memorials-popular-petcemeteries-europe (Accessed 31.08.2017).

Pickrell, John 2004. Oldest Known Pet Cat? 9,500-Year-Old Burial Found on Cyprus. National Geographic.

http://news.nationalgeographic.com/news/2004/04/0408_040408_oldestpetcat.html (Accessed 31.08.2017).

Pentikäinen, Juha 1990. Suomalaisen lähtö: Kirjoituksia pohjoisesta kuolemankulttuurista. Suomalaisen Kirjallisuuden Seuran toimituksia 350.Helsinki: Suomalaisen Kirjallisuuden Seura.

Pisiloomade netipesa 2005. Pisi.ee. http://www.pisi.ee/viewtopic.php?f=83\&t=3392 (Accessed 31.08.2017).

Premack, David \& Premack, Ann James. Why animals have neither culture nor history. Ingold, Tim (ed.). Companion Encyclopedia of Anthropology. London \& New York: Routledge, pp. 350-365.

Päärt, Villu 2004. Surnukuur küsis raha põrmu väljastamine eest. Postimees (15.04.2004).

Rahno, Paul 1965. Harku. Tallinn: Eesti Raamat.

Roadside Pet Cemetery 1996-2017. Roadside America.com.

http://www.roadsideamerica.com/story/30646 (Accessed 31.08.2017).

Stark, Tuula 1993. Pet Cemetry: "We'll take the Rose Now Between Her Paws and thus We'll Open the Heaven's Doors." Manuscript: University of Helsinki, Chair of Folklore.

Suviste, Maarius 2000. Kilpkonna peab matma nagu inimest. Maaleht (18.05.2000). 
Tarbija 24. Võru võib saada loomakalmistu. (13.11.2007)

https://www.postimees.ee/1726259/voru-voib-saada-loomakalmistu

Torp-Kõivupuu, Marju 2003. Surmakultuuri muutumine ajas: Ajaloolise Võrumaa matusekombestiku näitel. Monograafia. TPÜ Toimetised. Humaniora, 22. Tallinn: Tallinna Pedagoogikaülikool.

Torp-Kõivupuu, Marju 2004. Risti peale kirjutas: ühel papil oli peni... Eesti loomakalmistukultuurist. Mäetagused, 25, pp. 47-76.

http://dx.doi.org/10.7592/MT2003.25.loomakalmistud

The Association Of Private Pet Cemeteries And Crematoria 2016.

http://appcc.org.uk (Accessed 31.08.2017).

Uran: Tartu Saksa Lambakoerte Klubi ajakiri 2000 (2); 2002, (1; 3).

Varjupaigad

http://www.eau.ee/ astan/varjup.htm\#varjup (15.05.2004) (Accessed 31.08. 2017).

United cats. Forum.

http://www.unitedcats.com/et/forum/255/4291/lahkunud-lemmikud (Accessed 31.08.2017).

Vesik, Liisa 2003. Saak 2003: Ristirotid: Suhteid ühes yahoo.com suhtlusgrupis. Presentation at "Akadeemilise Rahvaluule Seltsi kogumiskonverents", 30.10.2003.

Viljandimaa Turismiinfokeskus.

http://www.viljandimaa.ee/turismiinfo/?mod=9\&sort=1\&id=114\&pk $\mathrm{nd}=(27.05 .2004)$.

Wiedenmann, Rainer E. 1993. Neuer Totemismus? Überlegungen zur Genese und Semantik moderner Tierbestattung. Soziale Welt, 44 (2), pp. 199-222.

Wolf, Michèle 1989. Tierfriedhöfe in Frankreich. Zeitschrift für Semiotik, $11(2 / 3)$.

http://ling.kgw.tu-berlin.de/semiotik/deutsch/ZFS/ Zfs89_2.htm\#wolf (Accessed 31.08.2017). 


\section{ELM Scholarly Press \\ SATOR 18}

http://dx.doi.org/10.7592/Sator.2017.18

\section{BALKAN AND BALTiCUM}

Current Studies in the Postsocialist Space

Edited by

Ekaterina Anastasova and Mare Kõiva

Tartu 2017 
Editors and compilers: Ekaterina Anastasova, Mare Kõiva Series "Sator" editor: Mare Kõiva

Language editors: Liisa Vesik, Lii Liin

Cover photo: Jaak Kikas, 2017 "Autumn in Tartu"

International committee

Tiiu Jaago (Tartu University); Reet Hiiemäe (Estonian Literary Museum); Mare Kalda (Estonian Literary Museum); Tarmo Kulmar (Tartu University); Nikolay Kuznetsov (Estonian Literary Museum); Aado Lintrop (Estonian Literary Museum); Emily Lyle (School of Scottish Studies in Edinburgh); Mirjam Mencej (Ljubljana University); Jonathan Roper (Tartu University); Marju Kõivupuu (Tallinn University); Ülo Valk (Tartu University); Tatjana Vladõkina (Institute of Udmurtian History, Language and Literarture, Izhkar); Irina Vinokurova (Institute of Karelian History, Language and Literarture in Petroskoi); Ergo-Hart Västrik (Tartu University)

Supported by Estonian Academy of Sciences, Bulgarian Academy of Sciences, the Centre of Excellence in Estonian Studies (CEES, European Regional Development Fund) and is related to research projects IRG 22-5 (Estonian Research Council).

\section{$\boldsymbol{C} E \mathbf{E} \times \begin{aligned} & \text { Centre of excellence } \\ & \text { in Estonian Studies }\end{aligned}$}

Series "Sator. Artikleid usundi- ja kombeloost", 18 http://www.folklore.ee/rl/pubte/ee/sator/sator18/

ISSN 1736-0323 (online)

ISBN 978-9949-586-58-5 (printed)

ISBN 978-9949-586-61-5 (online) ISSN 1406-2011 (printed)

DOI: 10.7592/Sator.2017.18

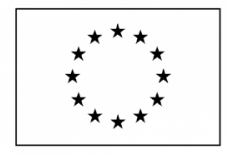

European Union European Regional Development Fund

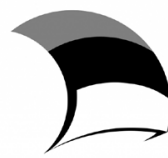

Investing in your future

\section{EUROPEAN UNION}

Regional Development Fund

Investing in your future
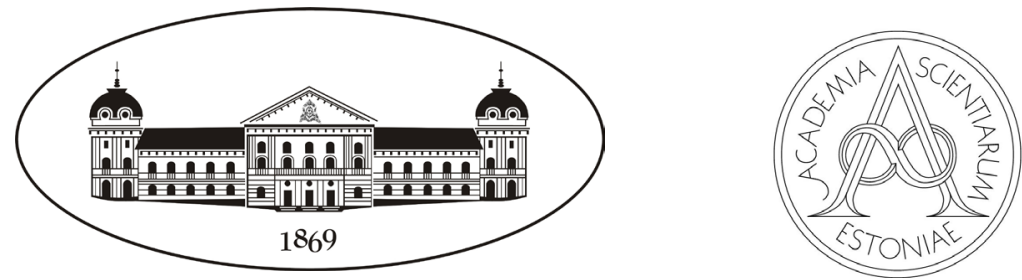


\section{Contents}

Preface

Mare Kõiva, Ekaterina Anastasova

CONSTRUCTING IDENTITY AND SOCIAL TIES

Ethnographic Studies on the Montenegrin

Festive Costume as a National Symbol

Sofiya Zahova

Social Ties of Bulgarians and Rudari in the Mediterranean Countries

Magdalena Slavkova

\section{RECASTING RELIGION AND \\ RELIGIOUS IDENTITY}

Contemporary Development of the Akyazili

Baba Tekke / St. Athanasius in Bulgaria

Yelis Erolova

Turkish Religious Identity in Bulgaria

94

in the Last Twenty-Four Years (1989-2013)

Mila Maeva

The Feast of Cyril and Methodius in Bessarabia and Crimea, Ukraine

Ekaterina Anastasova 
The Saints of Death in the Traditions

of the Balkan People

Rachko Popov

\section{CONSTRUCTING NEW SPIRITUALITY}

New Trends in the Study of Religion in Estonia -

Contemplations in the Grey Zone between

Religion and Science

Tõnno Jonuks

Constructing New Spirituality in Modernity -

the Case of the White Brotherhood in Bulgaria

Svetoslava Toncheva

Constructing Contemporary Periodical and

Occasional Rituals

Mare Kõiva

The Making of a Sacred Place:

221

An Example of Constructing Place Identity in the Contemporary Mentality

Reet Hiiemäe

\section{CHANGING TRADITIONS}

Bridge Over the Rainbow. Animal Burials and

Animal Cemeteries in Post-Socialist Estonia

Marju Kõivupuu

Simple Hide-and-seek at its Core: Play Features and the Game of Geocaching

Mare Kalda 